\title{
THE LAW CLERK'S DUTY OF CONFIDENTIALITY
}

Preserving the confidentiality of judges' work has been "an honored tradition among law clerks." 1 Former clerks, especially those of United States Supreme Court Justices, have occasionally published reminiscences of their court experiences, ${ }^{2}$ but "none of these [publications] has gone to details of particular cases or to work habits and attitudes of justices as they relate to other justices." ${ }^{3}$ This traditional secrecy recently was shattered by the publication of The Brethren ${ }^{4}$ and by the testimony of law clerks before a televised California judicial conduct investigation. ${ }^{5}$ The authors of The Brethren asserted that 170 former law clerks were among their anonymous sources and that "dozens of sources" handed over conference notes, diaries, unpublished opinion drafts, and internal memoranda between Justices. ${ }^{6}$ The California incident was less

1 Wright, Observations of an Appellate Judge: The Use of Law Clerks, 26 VAND. L. REv. 1179, 1189 n.38 (1973). See W.O. Douglas, THE Court Years: 1939-1975, at 174 (1980) ("In the long years I served, there was never any suspicion that a clerk violated a confidence of the Court."). But cf. Newland, Personal Assistants to Supreme Court Justices: The Law Clerks, 40 OR. L. Rev. 299, 310 (1961) (reporting a United States Supreme Court law clerk's 1919 leak of a forthcoming opinion to stock market dealers as the only leak leading to legal action against a Court clerk); B. Woodward \& S. ARMstrong, The Brethren 237-38, 150 (1979) (a law clerk provided background to Time magazine regarding a forthcoming decision; law clerks who played basketball with the Solicitor General's staff leaked decision dates).

2 See, e.g., Boskey, Mr. Chief Justice Stone, 59 Harv. L. Rev. 1200 (1946); Meador, Justice Black and His Law Clerks, 15 ArA. L. Rev. 57 (1962); Williston, Hotace Gray, 1828-1902, in 8 Great AmertaAn Lawyers 139 (W. Lewis ed. 1909). (1980).

3 Frank, The Supreme Court: The Muckrakers Return, 66 A.B.A.J. 161, 163

4 B. WoOdWARD \& S. ARMstrong, supta note 1.

5 Ordinarily such investigations in California are held in private, but a modification of the rule was obtained in this case. The public nature of the proceedings was successfully challenged by California Supreme Court Justice Mosk and declared violative of the California constitution. Mosk v. Superior Ct. of Los Angeles County, 25 Cal. 3d 474, 601 P.2d 1030, 159 Cal. Rptr. 494 (1979) (en banc).

6 B. Woodward \& S. Armstrong, stupra note 1, at 3-4. It seems clear that at least some clerks breached confidentiality, because former law clerks were major sources and the book "is based almost entirely on material and information that can, with some degree of accuracy, be considered to have been confidential before its publication there." Bender, Book Review (ThE BREthren), 128 U. PA. L. Rev. 716, 721 (1980); accord, Symposium, The Brethren: Yea or Nay, 15 U. PA. L. Alumar J., Summer 1980, at 17 [hereinafter cited as Symposium] ("There is very little room for disagreement ... that a great number of people broke confidences and provided information without restrictions.") (remarks of Professor Burbank). It should be noted, however, that not all of the 170 former clerks who were interviewed revealed confidential information. See Fletcher, Book Review (The Brethren), 68 Cal.IF. L. Rev. 168, 169 n.5 (1980) (author knows a number 
voluntary: a state judicial conduct commission subpoenaed law clerks to testify in a public investigation of alleged misconduct by California Supreme Court justices. ${ }^{7}$ Two justices instructed their clerks not to testify, but the staffs of the other justices cooperated and reported conversations with justices that clearly took place on the assumption of confidentiality. ${ }^{8}$

The breaches of confidentiality involved in The Brethren and the California investigation have caused concern among judges ${ }^{*}$ and commentators. ${ }^{10}$ Some have argued that such leaks will have an adverse impact on the judge-clerk relationship. ${ }^{11}$ Others, disagreeing generally with the secrecy surrounding the inner workings of the judiciary, have argued that such disclosures should be encouraged.12 Still others have expressed mixed emotions about the propriety of the disclosures. ${ }^{13}$

The law clerk's confidentiality duty, and the information to which the duty extends, are not well-defined. ${ }^{14}$ Because of the rela-

of clerks who talked but revealed no confidential information and mentions one outraged clerk who wrote to Newsweek magazine stating that he had answered only "general questions about the court").

7 Abramson, Should a Clerk Ever Reveal Confidential Information?, 63 JodrcaTuRE 361 (1980). The investigation concerned the alleged delay in announcing controversial decisions until after the retention election of four California Supreme Court justices, among them Chief Justice Bird. Tesitor, Calif. Commission Won't File Charges in Probe of Supreme Court, 63 Jodrcature 296 (1980). The investigation ended without any charges being filed. Abramson, supra, at 361 n.2.

8 Abramson, supra note 7 , at 361 . In view of the nature of the allegations, testimony presumably was taken concerning the handling of and discussions about the controversial cases.

9 See Henry, Book Review (The Brethrean), 47 Tenn. L. Rev. 495, 498-99 (1980). Several judges responding to the survey conducted for this Comment also expressed their disapproval. See note 15 infra \& accompanying text.

10 See, e.g., Kurland, Book Review (The BrethreN), 47 U. Chr. L. Rev. 185, 193 (1979) ("The Brethren likely will bring no shame to any except those who provided the offal that was packaged in this volume."); Tribe, Trying California's Judges on Television: Open Government or Judicial Intimidation?, 65 A.B.A.J. 1175, 1178 (1979) ("Nobody can seriously doubt that judges would be unable to perform their delicate mission of assuring equal justice under law if their thought processes and confidential deliberations could be subjected routinely to public gaze and official censure."); Breach of Court Secrecy Angers Former Clerks, NAT'L I.J., Dec. 17,1979 , at 17.

11 See, e.g., Daniels, Book Review (The Bretrren), 44 Arb. L. Rev. 732, 737 (1980); Kurland, supra note 10, at 193; Lewis, Book Review (THE Breithren), 52 N.Y. ST. B.J. 205, 211 (1980); Steinberg, Book Review (The BRETHREN), 66 A.B.A.J. 186, 188 (1980).

12 See, e.g., B. WoOdWARD \& S. ARMStrong, supra note I, at I; Miller \& Sastri, Secrecy and the Supreme Court: On the Need for Piercing the Red Velour Curtain, 22 BuFfato L. Rev. 799 (1973).

13 See, e.g., Bender, supra note 6, at 725; Symposium, supra note 6, at 16 (remarks of Professor Burbank).

14 See Symposium, supra note 6, at 16 ("These responsibilities [of a law clerk] ... have not been well-defined.") (remarks of Professor Burbank). 
tive paucity of research concerning these issues, a survey of the practices and opinions of a nationwide sample of federal and state judges was conducted to supplement other source material. ${ }^{15}$ This Comment discusses the conclusions that may be drawn from analysis of the survey results and other available information. Part I examines the nature of the judge-clerk relationship and current practices concerning clerk confidentiality. Part II discusses the nonlegal rationales for and against confidentiality. Part III analyzes the legal and ethical bases for a confidentiality duty on the part of law clerks. Part IV then proposes guidelines for specific aspects of the law clerk's confidentiality duty and a method for enforcing the proposed guidelines.

\section{The Judge-Clerk Relationship and Gurrent Confidentiality Practices}

The judge-clerk relationship is multifaceted and has been described as including teacher-pupil, employer-employee, and lawyerlawyer relationships. ${ }^{16}$ The clerk also may serve as a confidant or friend, adding a personal component to the relationship. ${ }^{17}$ The teacher-pupil ${ }^{18}$ and lawyer-lawyer aspects are revealed by the interchanges between judges and clerks. On the one hand, law clerks

15 A copy of the postal questionnaire and a discussion of the sample is contained in the Appendix infra. Survey recipients were assured that the presentation of findings would not permit the identification of individual courts or judges. Survey results are on file at the University of Pennsylvania Law Review office.

16 A. Dileo \& A. Rubin, Law Clenk Handbook 39 (1977).

17 Clerks' reminiscences often describe the development of warm personal relationships with their judges. See, e.g., Chief Justice Vinson and His Law Clerks, 49 Nw. U. L. Rev. 26 (1954); McCormack, A Law Clerk's Recollections, 46 Colum. L. Rev. 710 (1946). Several survey respondents also described their relationships with clerks as "close" or "open." The employment of multiple clerks per judge, however, is likely to dilute these close relationships. See Symposium, supra note 6, at 17 ("The result [of the increasing number of clerks per chambers] is that the simple personal relationship is far more distant than it used to be.") (remarks of Professor Burbank).

18 Justice Gray of the Supreme Court, for example, apparently "treated the Iaw clerk much as a law professor would treat a student, exploring the clerk's views and only implicitly revealing his own." Oakley \& Thompson, Law Clerks in Judges" Eyes: Tradition and Innovation in the Use of Legal Staff by American Judges, 67 CALIF. L. REv. 1286, 1289 (1979). One federal district court judge's outline of the duties of his law clerks includes the discussion of cases under advisement. He describes the process as follows:

I like for my clerks to question my preliminary judgment and to suggest their own ideas for my consideration. While ... my primary interest must be the work product of the clerk and its assistance to me in the judicial process, I think the period of clexkship should be a significant experience for the clerk and should serve to broaden his own background and abilities.

A. DILEo \& A. RuBn, supra note 16, at 11-12. 
are short on experience and seek to gain an operational view of the judicial decisionmaking process. ${ }^{19}$ On the other hand, many judges value clerks straight from law school precisely because recent graduates have been exposed to the latest doctrinal developments and usually have a fresh viewpoint. ${ }^{20}$ Communications between judge and clerk about cases and opinions not only serve the educational interests of the clerk but also present an opportunity for the judge to test, refine, and clarify ideas. ${ }^{21}$

The use of law clerks by judges has grown enormously since the inception of the practice. ${ }^{22}$ The "traditional" law clerk-the short-term recent law school graduate assigned to a particular judge

19 Abramson, supra note 7 , at 361 (The clerkship is a "valued interlude between law school and lawyering, a cap on one's legal education by way of example set by the judge as tutor."); Baier, The Law Clerks: Profile of an Institution, 26 VAND. L. REv. 1125, 1161-62 (1973); P. Barnett, Law Clerks in the United States Courts and State Appellate Courts 4 (Nov. 1973) (Am. Jud. Soc'y Research Study).

20 See Baier, supta note 19, at 1141; ABA Comm. on Standards of Judrctar Adminzstration, Standards Relating to Appellate Courts 97-98 (1977).

Justice Douglas was opposed to Chief Justice Burger's experiments with permanent clerks because of his preference for "fresh minds." He noted:

Under [a permanent clerk] system the law clerks would acquire more and more power, with no fresh minds coming in annually to ventilate the old stuffy chambers; under such a system the ideas of the "boss," usually stuffy and stereotyped, would never be challenged. That movement would mean the end of the seasoning of the pudding-it would eliminate the spice that fresh young minds [bring] to the job.

W.O. Dovglas, supra note 1 , at $\mathbf{1 7 5}$.

21 Braden, The Value of Law Clerks, 24 Miss. L.J. 295, 296 (1953) ("Discussion of a case serves to clarify a man's thoughts, and a clerk can be of great value to a judge by asking pointed questions, posing alternatives, and generally acting as a devil's advocate."). as follows:

One appellate judge has described the benefits of conferring with his clerks

[T]he judge will often find it profitable to confer at length with his clerk. In order to test his tentative conclusions, the judge may require the clerk to defend the opposing position or the judge himself may reverse roles, attacking his own opinions. The interchange is often quite beneficial to the judge, enabling him to look at an issue from an entirely different angle. ... [T]hese conferences ... will often help the judge to understand better his own position. ...

Wright, supra note 1, at 1187-88 (footnote omitted).

22 The practice began in 1875 with Horace Gray, then Chief Justice of the Massachusetts Supreme Court. Justice Gray continued this practice when he was appointed to the United States Supreme Court in 1882. Oakley \& Thompson, supra note 18, at 1289-90. Since that time the institution has multiplied so that law clerks now serve on all federal court levels, all but six of the highest state appellate courts, and all but three intermediate state appellate courts. P. Barnett, supra note 19, at 1. Moreover, there has been a trend toward having more than one clerk per judge or justice. Since 1970, the United States Supreme Court Justices have had at least three clerks, and federal courts of appeals judges have had at least two; since 1965, federal district judges have had the option of having a second law clerk in lieu of a court crier. Oakley \& Thompson, supra note 18, at 1291. The Supreme Court of California in 1976 employed thirty-three "research attorneys" for seven justices. Id. 1302 . 
-is still the predominant mode, although some jurisdictions employ a "central staff" unassigned to particular judges ${ }^{23}$ or "career clerks" who have indefinite tenure. ${ }^{24}$

The law clerk's general function "is to participate in processing effectively and fairly the litigation assigned." ${ }^{25}$ The specific duties of the law clerk vary with the court and the particular judge served, ${ }^{26}$ but may include research, drafting, editing, cite checking, proof reading, document assembly, conference attendance, reading and indexing slip opinions, errands, library maintenance, and discussions with the judge. ${ }^{27}$ Judges generally prepare findings of fact or opinions, then ask their clerks to review them and to check or

23 Because of indications that a justice's productivity was not increased significantly by the addition of extra law clerks to his personal staff, the Michigan Court of Appeals initiated the use of "central staff" as a response to increasing caseloads. Lesinski \& Stockmeyer, Prehearing Research and Screening in the Michigan Court of Appeals: One Court's Method for Increasing Judicial Productivity, 26 VAND. L. REV. 1211, 1213-14 (1973).

24 The use of career clerks to the virtual exclusion of traditional short-term clerks is "apparently unique to California." Oakley \& Thompson, supra note 18, at 1294.

25 A. DILEO \& A. RUBin, supra note 16, at 4. An annotated bibliography of materials dealing with the role and experiences of Supreme Court clerks may be found in Garcia, The Role and Experiences of Supreme Court Law Clerks: An Annotated Bibliography, 70 L. LIB. J. 338 (1977).

26 Barnett, supra note 19, at 3. Justice Douglas noted some variations of law clerk use by Supreme Court Justices:

Holmes ... took a clerk largely as a companion. Brandeis used a clerk as researcher for the voluminous footnotes often found in his opinions. Stone would dictate his opinions, and when he stated a principle of law he would say in parentheses "Cite cases." The draft would go to the clerk, who would then look for the cases supporting Stone's position. . . .

Justice Murphy ... relied heavily on [his law clerk] in preparing the first draft of his opinions for the Court. ...

I used my law clerks primarily to certify the accuracy of my opinions as to facts and precedents. . . The law clerk would write a memorandum on each petition for certiorari and on each jurisdictional statement, but I went over each case independently of him. . . . [A]t times I asked him to draft a concurring or dissenting opinion for me, which $I$ in turn would revise or rewrite.

W.O. Douglas, supra note 1 , at 171-72. Courts that use some clerks as part of a "central staff" usually assign specific functions to that group. For example, the Michigan Court of Appeals uses its central division to research and screen appeals prior to hearing. Lesinski \& Stockmeyer, supra note 23, at 1213.

27 A. DiLeo \& A. RuBLN, supra note 16 , at 3, 12-16. Trial court clerks tend to have more contact with attorneys, witnesses, fact-finding and discovery; appellate court clerks' primary activities are research and drafting. Id. 5-6. Judge Henry Friendly of the United States Court of Appeals for the Second Circuit has described his use of law clerks as primarily for cases "where it is apparent that a fair amount of added research will be needed before I can come to any conclusion." H. Friendly, How a Judge of the United States Court of Appeals Works (1962) (New York, Institute of Judicial Administration), quoted in Wright, supra note 1, at $1189-90$. 
add citations. Glerks also may be asked to draft findings or opinions. ${ }^{28}$

Because of their position, clerks have a unique view of their judges and other court personnel. They also have access to opinion drafts, internal memoranda, and information gleaned from discussions with judges, none of which are made public once a decision is reached. Prior to announcement of a decision, the clerk may have information concerning the scheduling of a case and its probable or certain outcome. Clerks who develop close personal relationships with their judges also may be aware of the judges' political philosophies or personal feelings about particular lawyers, litigants, other judges, or cases.

Despite the clerk's access to confidential material and the concern provoked by the perceived impropriety of particular disclosures by law clerks, ${ }^{29}$ there exists no uniform code of professional responsibility for law clerks. ${ }^{30}$ For example, a variety of answers has been offered by commentators considering the question to whom a clerk may speak concerning past and present cases. Answers vary from the permissive to the restrictive: allowing communication between clerks and spouses, ${ }^{31}$ limiting discussion to the "court family," 32 using discretion within the court, ${ }^{33}$ and prohibiting speaking outside the individual chambers. ${ }^{34}$

28 A. Dileo \& A. Rubin, supra note 16, at 12.

29 See notes 9-11 supra \& accompanying text.

30 Adoption of a code of conduct for law clerks is being considered by the Advisory Committee on Codes of Conduct of the Judicial Conference of the United States. Aoministrative Office of the United States Courts, Report of the Proceedings of the Judicial Conference of the Untred States 82 (Sept. 24-25, 1980). Arguably the Code of Judicial Conduct applies to certain behavior by clerks via their judges' authority over them. See text accompanying notes 107-08 infra.

31 See Baier, supra note 19, at 1145 n.88 ("Justice Tate was of the view that so long as the confidential nature of the discussion is understood by both parties, there is nothing wrong with an exchange of ideas between clerks about cases currently pending ... or with an after-office dialogue between husband and wife, often unavoidable anyway.").

32 See Wright, supra note 1 , at 1189 n.38 ("What matters is that the judge's work product must be kept exclusively within the court's family; it should not be shared even with the family of the clerk."); Hamley, Sample Instructions to Law Clerks, 26 VAND. L. REv. 1241, 1242 (1973) ("You may, unless instructed otherwise by your judge, discuss court cases with other law clerks, provided you cannot be overheard by others not connected with the court. But do not discuss undecided cases with your wife or anyone else outside the court.").

${ }^{33}$ See Aldisert, Duties of Law Clerks, 26 VAND. L. Rav. 1251, 1256 (1973) ("[A]lways be very discreet in your discussions with law clerks or other judges. . . . [I]t is improper to convey personal impressions of these chambers to other chambers.").

34 See Baier, supra note 19, at 1143 n.82 (noting Justice Brandeis's instructions to his clerk, Louis Jaffe: "He once told me that I was never to let anyone know what we were working on, not even the secretaries of the other Justices."). 
Individual judges or courts generally have forged their own policies that vary considerably in content, specificity, and formality. The survey revealed that an oral instruction about confidentiality at the beginning of a clerk's tenure is the most common practice. ${ }^{35}$ Some jurisdictions have local court rules concerning the release of information by court personnel, but these usually are limited to information about pending cases. ${ }^{36}$ Some courts and judges provide manuals for their clerks' use; the manuals vary in content and specificity. ${ }^{37}$ The survey also revealed that a few judges require a written agreement or oath promising confidentiality by their clerks, ${ }^{38}$ while some judges provide no instructions to their clerks.

\section{The Confidentiality Issue}

\section{A. The Importance of Preserving Confidentiality}

The necessity for frank and open communication in an atmosphere of trust is the reason most frequently given by commentators and judges for preserving the confidentiality of the inner workings of the judiciary. Breaches of confidentiality, it is argued, will result in curtailment of open discussion that will, in turn, impair effective functioning of both judge and clerk and damage their relationship. ${ }^{39}$

35 Ninety-four percent of the survey sample reported using oral instructions.

${ }^{36}$ A typical rule provides that "[a]1l courthouse personnel, including . . . Law Clerks . . . are prohibited from disclosing to any person, without authorization from the Court, information relating to any pending civil or criminal case that is not part of the public records of the Court." M.D. LA. R. 24. Some rules are limited to pending criminal matters. See, e.g., E.D. LA. R. 13.8.

37 About half of the survey respondents reported using manuals, often in conjunction with oral instructions. A handbook used by some federal judges provides that "everything that occurs in the process of decisionmaking and all statements or events that do not occur in open court or in open conference with attorneys present" are within the clerk's confidentiality duty. A. DiLeo \& A. RuBiN, supra note 16, at 41 . This handbook, although published by the Federal Judicial Center, expresses the views of its authors and has no official status. "Each judge will have his own approach, and will wish law clerks to handle problems in the manner considered most appropriate." Id. Foreword. One court's manual, provided by a survey respondent, indicates that clerks have the responsibility to preserve "professional confidences." It specifies that revelations concerning pending matters such as "the names of cases in which memoranda or dispositions are being prepared, the weights of particular cases, or the names of the judges assigned to cases not yet argued or submitted" is prohibited. General information about staff functions may be discussed, but internal memoranda are confidential "both during the pendency of the case and after decision by the court."

38 Nine percent reported using an oath or a written agreement or both. See note 102 infra \& accompanying text.

39 See notes 16-2l supra \& accompanying text for a discussion of the nature of the typical working relationship between judge and clerk. The opportunity for a judge to test and clarify ideas and the ability of the clerk to assist in the decisionmaking process would be impaired if discussion were markedly limited. 
Our survey findings strongly support this argument. Responding judges frequently mentioned the necessity of preserving free and open communications between judges and clerks as a basis for a clerk's confidentiality duty. ${ }^{40}$ One judge, for example, articulated this concern as follows:

My relationship with my law clerks is a close and confidential one. If I cannot speak freely to them, they cannot do their job for me. And I could not speak freely to them if I thought that my questions, soul-searching, and opinions would be made matters of public record or private conversation. There is often a good deal of give and take and what finally emerges may not have been anyone's original thought. If my half-formed ideas or preliminary thoughts are not kept confidential by my law clerks-then I will have to keep them confidential myself and that will seriously impair the decision-making process.

Judges were asked how a breach of confidentiality by a law clerk might affect their relationships with other clerks-for example, by limiting the range or type of discussion or by influencing their preference for permanent clerks. ${ }^{41}$ Only thirty percent of the responding judges felt there would be no impact. Slightly over half felt there would be or had been a negative impact on the closeness of the relationship or on the range and type of discussions with clerks. ${ }^{42}$ Topics specified by some judges as candidates for ex-

40 These responses were in answer to questions 1 and $4(f)$ of the survey. See Appendix infra, for text of these questions.

41 See question 7, Appendix infra, for precise wording of the question used. One of the predicted effects of the leaks involved in The Brethren was a negative impact on the judge-clerk relationship because of more circumscribed discussion or less intimacy. See, e.g., Daniels, supra note 11, at 737; Grossman, Book Review (ThE BretrireN), 1980 WIs. L. Rev. 429, 439; Kurland, supra note 10, at 193; Lewis, supra note 1I, at 211; and Steinberg, supra note 11, at 188.

42 Judges' estimates of the strength of the impact varied. Typical strong statements are illustrated by the following two comments:

A Judge will be a fool only once. If a single law clerk reveals things about a judge's methods, habits, speech (expletives, for example), reliance on briefs, law clerks, overuse of law reviews, etc., the Judge will simply have an arm's length relationship of great formality so all a law clerk sees is what the public sees. They will not be very useful after that.

I believe a breach of confidence would make the work of future law clerks less interesting, less rewarding, and less effective because I would clam up and tell them a whole lot less than I tell them now when I treat them like lawyers and trust them. Without trust, I'd probably find a good lexis operator and forget about law clerks.

Another judge, however, was more ambivalent about the impact of leaks on discussion:

This is difficult to answer since I desire to have as open a relationship as possible with my law clerks-this is helpful to me as well as to the law 
purgation if a breach of confidentiality was considered likely included court votes, court attitudes, the judge's own votes and attitudes, opinions about the effect of another judge's political philosophy on his or her decision in a particular case, anger about another judge's views, and the effect of a colleague's views on the structure of an opinion.

The comments of some survey respondents who reported that they or their courts had experienced a breach of confidentiality by a law clerk ${ }^{43}$ demonstrates the reality of the negative impact of leaks. One judge replied: "Yes-definitely-[a breach] always does [affect discussions]. You keep such vital information to those with a need to know. I do not let law clerks take outside calls on pending cases." Other judges, desiring to maintain a fruitful working or personal relationship, use a cautious but less drastic approach: "I tend to be more guarded in my confidences with my new clerks until I'm satisfied they are honorable," "[a breach] always inhibits my relationship with my present clerks, makes me more inhibited, at least temporarily," and "[a]ny fear of continuous breaches would make my life miserable, for I would have to further retreat into privacy."

The concern of many judges was demonstrated by their emphasis on the need for clearer policies regarding confidentiality, whether effectuated informally through selection and training procedures or formally through mechanisms such as oaths and written agreements. Almost two-thirds of the survey respondents expressing an opinion on the issue indicated that a breach of confidentiality would prompt them to take more care in selecting and orienting their clerks. Approximately one-third stated that their reaction would be to adopt a formal policy, such as requiring clerks to take an oath or to sign a written agreement.44

clerk. I suspect a breach of confidentiality would make me more cautious and [might] limit discussions with my law clerks.

43 Eighteen percent of the respondents fell into this category. Judges were asked if they or their courts had experienced any incidents that they considered breaches of confidentiality. See Appendix infra, question 6, for precise wording. "Breach of confidentiality" purposely was not defined. This approach turned out to be justified in light of varying opinions of the scope of the duty expressed by survey respondents.

44 Comments typifying the formal approach included the following: "Any breach (other than an inadvertent one ... ) would cause me to insist to my colleagues that we adopt a formal, written policy re confidentiality and require our clerks to sign an oath of confidentiality"; "It would make me rethink my practice of not requiring a specific agreement of confidentiality," and "It might suggest use of a 'Snepp' type contract, or if egregious enough a court rule or statute." See text accompanying notes 104-10 infra for discussion of Snepp v. United States, 444 U.S. 507 (1980) (per curiam). 
Finally, seventeen percent of the survey respondents said that a breach would affect their preference for hiring permanent clerks. Some reported that a change to permanent staff would be a "last resort." Others felt that permanent clerks may become an attractive alternative, especially if the confidentiality problem is perceived as chronic. For example, one judge who has experienced confidentiality breaches stated:

I have considered permanent clerks on occasion for this and other reasons but have decided against it because the confidentiality problem has not been severe. ... I gain greatly from the interest and enthusiasm of bright, new graduates of law schools and I am as yet unwilling to deprive myself of that pleasure. If the problem should become severe, I might reconsider.

A second argument for preserving confidentiality is the need to protect judges' independent reasoning from outside influences. ${ }^{45}$ One proponent of this view suggests that "we need courts independent enough to serve as 'safe asylums' in times of crisis. They cannot do so if threatened with mind probes whenever they render judgments out of tune with popular sentiment." 48 Without confidentiality, judges "will fear ... the candid and vigorous internal disagreements without which the judicial process would be rendered vastly less thoughtful and ultimately less effective." 47 Former Chief Justice Earl Warren similarly argued that the process between argument and the announcement of a decision "is, of necessity, confidential. ... Throughout the decision-making process, members of the Court are left to their own consciences in the quiet of their chambers to reflect on the facts and the applicable law, except for any discussion they might have with their colleagues on the merits of their cases." 48

Preserving public confidence in the judiciary is a third reason for maintaining the confidentiality of a court's deliberations. Several survey respondents emphasized this theme. For example, one judge commented that a "court does consider factors which should ultimately be and are discarded as meritless. Public display of such considerations in retrospect would afford ground for ridicule." Another judge felt that "good procedure" requires that the judge's

45 See, e.g., Miller \& Sastri, supra note 12, at 817; Tribe, supra note 10, at 1178.

46 Tribe, supra note 10 , at 1177 .

47 Id. 1178.

48 E. Warren, The Memoirs of EarL. Warren 337 (1977). 
opinion "stand as the rationale of the case, without a clerk's prognostications." Similarly, commentators have argued that although a court's opinion may be the result of compromise, the opinion should stand alone because "it is the compromise that is relevant to the legal profession and the public; and the fact that some [judges] may have harbored a no-compromise position or that the original draft of the Court's opinion was more forceful is only of incidental concern to the legal analysts and historians." 49

Protecting litigants and others who might be affected by a decision is a fourth reason for maintaining confidentiality. ${ }^{60}$ Although some commentators argue that all court deliberations should be open, ${ }^{51}$ an overwhelming majority of judges and commentators agree ${ }^{52}$ that preserving the confidentiality of deliberations in pending cases is necessary to prevent one party from gaining an unfair advantage or an outside person from exploiting advance knowledge of a decision. ${ }^{53}$

Protecting a judge's reputation ${ }^{54}$ and legitimate privacy interests is an additional reason supporting confidentiality. For example, several commentators on The Brethren were distressed by the revelation of incidents such as the details of Justice Douglas's last illness and Justice Stewart's personal reasons for not being interested in becoming Chief Justice. ${ }^{55}$ Judicial inquiry and disciplinary practices in forty-seven states reflect this concern. Their pro-

49 Gressman, Irreverent Questions About Piercing the Red Velour Curtain, 22 Bufrazo L. Rev. 825, 829 (1973) ("[T]he Court's opinion writers generally and accurately incorporate the significant suggestions of their colleagues."). See also E. WARREN, supra note 48 , at 282.

50 See, e.g., Henry, supra note 9, at 499 ("[T]he ultimate rights of litigants may only be protected when judges may explore the issues, adjust their thinking, and formulate decisions without fear of attendant publicity."). Even the authors of The Brethren did not interview clerks for the three year period preceding publication "[t]o ensure that [their] inquiry would in no way interfere with the ongoing work of the Court ...." B. WoodwaRd \& S. ARMstrong, supra note 1, at 2.

51 See notes 59-64 infra \& accompanying text.

52 See, e.g., Bender, supra note 6, at 721; Henry, supra note 9 , at 499 . For a discussion of law clerk confidentiality in pending cases, see notes $137-49$ infra and accompanying text. All survey respondents indicated that the confidentiality duty extends to information about pending cases.

53 The 1919 leak case, for example, involved the exploitation of advance information about decisions to speculate in the stock market. P. Barnett, supra note 19 , at 1 . See note 1 supra.

54 Cf. Mosk v. Superior Court of Los Angeles County, 25 Cal. 3d 474, 491, 601 P.2d 1030, 1041, 159 Cal. Rptr. 494, 505 (1979) (en banc) (confidentiality of judicial investigations and hearings "protects judges from injury which might result from publication of unexamined and unwarranted complaints").

55 See, e.g., Henry, supra note 9, at 496; Navasky, Book Review (TrE Brethreen), 89 YALE L.J. 1028, 1030 (1980). 
cedures provide for confidentiality at least until a formal complaint is filed with the supreme court or equivalent body. ${ }^{58}$

Related to privacy and reputation interests of judges and public confidence in the judiciary is the perceived need to guard against inaccuracies in, and distortions of, law clerks' disclosures. One of the strongest criticisms of The Brethren, for example, is that the law clerk's perspective is limited or distorted. ${ }^{57}$ Additionally, there is concern that disclosures will be distorted by those seeking the information, especially journalists. ${ }^{58}$ Several survey respondents voiced these concerns. One said that information about judges "often involves an unfounded assumption that the clerk's opinions are necessarily objective and unaffected by his own personal views or personal relationship with the judge. Whatever the case, the judge is in no position to reply, even if the comment is false or unjustified." Another noted that "[a]s The Brethren has shown, personal or judicial comments made by judges to their clerks can be misquoted, distorted, or so taken out of context that they have no value except to undermine the public's confidence in the judiciary."

\section{B. Rationales for Limiting Confidentiality}

Several rationales have been advanced that support limiting the confidentiality of the inner workings of the courts. First, courts are political institutions, deciding general governmental policies in such sensitive areas as segregation, abortion, and capital punishment.59 "[B]asic democratic theory," requiring "knowledge not only of who governs but of how policy decisions are made," thus requires that the courts' decisionmaking processes be open to the public and subject to informed criticism. ${ }^{60}$

${ }^{56}$ Landmark Communications, Inc. v. Virginia, 435 U.S. 829, 834 (1978).

67 It has been suggested that law clerks are one-sided and nonobjective sources. See, e.g., Aynes, Book Review (The Brethren), I3 Akron L. Rev. 507, 513 (1980); Goldberg, A Former Justice on 'The Brethren', NaT'L L.J., Jan. 21, 1980, at 14. Moreover, it has been argued that law clerks lack firsthand knowledge of many things-for example, judges' conference deliberations. See, e.g., Daniels, supra note 11 , at 733-34; Goldberg, supra, at 14 .

68 An example of a distortion potentially damaging to reputation in The Brethren is the allegation that Justice Brennan voted against his conscience in a criminal case in order to curry favor with another Justice. See B. Woopward \& S. ARMSTRONG, supra note 1, at 225. An independent investigation of the clerks employed during the period in question revealed that they all denied reporting or knowledge of such an incident. Lewis, supra note 11, at 205-07.

59 Abramson, supra note 7, at 402. See also Kurland, supra note 10, at 195.

60 Miller \& Sastri, supra note 12, at 799 (emphasis in original); See also id. 822. If deliberations were publicly held, there would be little to keep confidential. The desirability or effectiveness of open deliberations, however, is questionable. See, 
A second rationale focuses on the public need to know how decisions are made in order to use the judicial system effectively and, where judges are elected, to make informed voting decisions. ${ }^{61}$ This rationale calls for some exploration of the inner workings of the courts. ${ }^{62}$ It no longer seems open to doubt that judges' decisions are based partially on their values and preferences. ${ }^{63}$ If judicial processes are surrounded by secrecy, the public is deprived of information that may be helpful in evaluating judges and the judicial system. ${ }^{84}$

Finally, wrongdoing or impropriety on the part of the judiciary ${ }^{65}$ should justify a breach of the normal confidentiality of judicial deliberations. ${ }^{60}$ Limiting the confidentiality of court processes will facilitate discovery and correction of wrongdoing because law clerks will be more likely to disclose any knowledge of such conduct if they do not fear breaching a confidentiality duty.

e.g., Gressman, supra note 49, at 826 (open deliberations could either destroy "valuable interplay of individual viewpoints" or force judges to "retreat to more private techniques of decision making"); Grossman, Comments on "Secrecy and the Supreme Court", 22 Buffato L. Rev. 831, 835 (1973) (an openness more "apparent than real" might be the result); Howard, Comment on Secrecy and the Supreme Court, 22 Bufralo L. REv. 837, 839 (1973) (private deliberations prevent premature judgments). The proper scope of, and forum for, such criticism also is debatable. See notes 167-70 infra \& accompanying text. Nevertheless, the idea of judicial immunity from all external scrutiny is antithetical to the judiciary's "political" function in a democratic society.

61 Abramson, supra note 7 , at 403 .

62 This was the basic premise underlying The Brethren, B. WoODWARD \& S. Armstrong, supra note 1 , at $I$. Other commentators have argued that the public has an interest in the deliberate processes of a policymaking body such as the Supreme Court. Some disagreement over the frequency and timing of such exploration has been expressed. Compare Bender, supra note 6, at 724 (might disapprove if exploration occurred in the present and on a daily basis) with Miller \& Sastri, supra note 12, at 799 (recommending open deliberations).

63 "Behind the logical form lies a judgment as to the relative worth and importance of competing legislative grounds, often an inarticulate and unconscious judgment, it is true, and yet the very root and nerve of the whole proceeding." O.W. Houmes, The Path of the Law, in Colrecten Legal Papers 181 (1920).

It may not be feasible to assess the impact of these unarticulated values. See Gressman, supra note 49 , at 826 . The internal procedures of a court are distinguishable from the unarticulated values of judges, however, because such procedures are susceptible of apprehension.

64 Survey respondents provided little support for the right-to-know rationales, although a few judges noted the people's or history"s right to know "certain matters."

65 See note 182 infra.

${ }^{68}$ Several commentators on The Brethren hinted they might have been less critical of the exercise if judicial wrongdoing or abuse of power had been involved. See, e.g., Kurland, supra note 10, at 190; Lewis, supra note 11, at 212 . See notes $182-92$ infra \& accompanying text for discussion of the wrongdoing exception to the confidentiality duty. 


\section{Bases of a Law Glerk's Confidentiality Duty}

The legal and ethical bases of a law clerk's confidentiality duty can be viewed on at least four levels-an informal moral obligation, ${ }^{6 \tau}$ an articulated but nonbinding professional responsibility, ${ }^{68}$ a binding fiduciary or contractual obligation, ${ }^{69}$ and a formal duty imposed by court rule or statute. ${ }^{70}$ Survey respondents ${ }^{71}$ mentioned each of these bases as follows: fiduciary duty (sixty-three percent); Code of Professional Responsibility (fifty-one percent); moral or "other" (thirty-one percent); contract (twenty-two percent), and court rule or statute (twenty-three percent).

Such a diversity of bases thought to underpin the confidentiality duty helps to explain the undefined content and scope of a law clerk's responsibility ${ }^{72}$ and the differing reactions to disclosures made by former Supreme Court clerks to the authors of The Brethren. ${ }^{73}$ The varying bases also may reflect the varying practices used by different courts. For example, some jurisdictions have relevant court rules or statutes while others do not; some jurisdictions hire clerks who are already members of the bar, a practice that could affect the applicability of the Code of Professional Responsibility. Judges requiring written agreements may be more likely to believe there is a contractual basis to the duty.

\section{A. Moral Obligation}

A law clerk's moral obligation to preserve confidentiality arises from the loyalty and trustworthiness inherent in the nature of the clerkship. ${ }^{74}$ Survey respondents who checked "other" as a basis of confidentiality mentioned many of the rationales supporting confidentiality ${ }^{75}$ but particularly emphasized the clerk's personal loyalty to the judge and to the court. Fifteen percent of the respondents specified no additional legal or professional ethical bases, indicating a belief that the law clerk's confidentiality duty is exclusively rooted in moral grounds.

\footnotetext{
67 See notes 74-82 infra \& accompanying text.

68 See notes 83-99 infra \& accompanying text.

60 See notes 100-15 infra \& accompanying text. spondents indicated more than one basis.

72 See note 14 supra \& accompanying text.

73 See notes 9-13 supra \& accompanying text.

74 See notes 16-21 and 25-28 supra \& accompanying text.

75 See notes $40-58$ supra \& accompanying text.
}

70 See note 36 supra, note 152 infra, and text accompanying note 116 infra. 71 See question 4 of Appendix infra for wording of question. Many re- 
There is a social expectation that relationships characterized by intimacy and friendship, such as that between judge and clerk, ${ }^{78}$ call for loyalty and trustworthiness. ${ }^{77}$ Many judges consider their clerks extensions of themselves; a breach of confidence, therefore, may be regarded as a personal betrayal. ${ }^{78}$ Comments of some survey respondents show that their expectation of loyalty is based on the personal nature of the judge-clerk relationship: "The working relationship between judge and clerk is intimate and dependent, and the judge should not have to be on guard for fear that a spur of the moment comment or an expression of a confidence will be made public" and "[m]utual confidence is essential to the relationship which should be and remain essentially personal as between clerk and judge, as if the clerk were a part of or extension of the judge."

Loyalty to a judge and to the court thus would prevent a clerk from revealing anything said in confidence that might undermine the judge's or the court's functioning or reputation. Both personal and institutional loyalty, however, rest on an individual clerk's conscience, discretion, and judgment. The only sanctions are a guilty conscience, disapproval, discharge, or a potentially negative impact on future employment opportunities if a breach is publicized. Loyalty is therefore an unreliable and unpredictable protector of confidentiality. Individuals may differ in their definitions of detrimental information. ${ }^{79}$ Personality or philosophical conflicts between clerk and judge may result in a lowered sense of personal loyalty by the clerk. ${ }^{80}$ Furthermore, the dilution of the personal judge-clerk relationship attendant on the practice of employing multiple clerks per judge ${ }^{81}$ and the use of "central staff" 82 similarly may lead to a dilution of the clerk's sense of loyalty.

76 See note 17 supra \& accompanying text.

77 See Henry, supra note 9, at 499 ("It is imperative that an appellate judge have the complete loyalty and confidence of his or her clerk."). Cf. Breach of Court Secrecy Angers Former Clerks, supra note 10, at 17 (one former clerk termed revelations by his colleagues as "a complete breach of faith").

${ }^{8}$ Some survey respondents who reported that they had experienced a breach of confidence described their reaction as one of anger, disappointment, or hurt.

79 For example, some clerks were willing to reveal a great deal and others only spoke of "general" matters to the authors of The Brethren. See note 6 supra. Cf. Breach of Court Secrecy Angers Former Clerks, suprc note 10, at 17 (some former clerks reportedly were outraged at the revelations of some of their former colleagues).

80 This difficulty may be overcome partially by careful selection of candidates; several survey respondents mentioned more careful screening as a desirable protective mechanism.

81 See notes 17 \& 22 supra; Bender, supra note 6, at 724 n.48.

82 See note 23 supra \& accompanying text. 


\section{B. Professional Responsibility}

Two codes of professional conduct-the ABA Code of Judicial Conduct $^{83}$ and the ABA Code of Professional Responsibility ${ }^{84}$ arguably serve as bases for a law clerk's confidentiality duty, either by implication or by analogy. The Code of Judicial Conduct directly applies only to judges, but "it serves as a model for standards of conduct required of all employees and officials of the judicial branch." 85 Moreover, Canon 3B(2) of the Code provides that "[a] judge should require his staff and court officials subject to his direction and control to observe the standards of fidelity and diligence that apply to him." ${ }^{88}$ By implication or through the judge's role as employer, therefore, a law clerk may be subject to this code. ${ }^{8 t}$

For purposes of defining the clerk's confidentiality duty, however, the Code of Judicial Conduct is limited. It requires that the judge, as employer, exercise control and supervision over the clerk; it makes the clerk responsible to his or her employer for "fidelity and diligence" rather than to any external standard. Whatever the scope of confidentiality, a uniform external standard providing direct guidance to law clerks seems more likely to encourage clerks to maintain confidentiality 88 than the indirect standard provided by the Code of Judicial Conduct.

The Code of Professional Responsibility could be used as a basis for the clerk's confidentiality duty by analogizing the clerkjudge relationship to the attorney-client relationship ${ }^{89}$ and arguing that a clerk owes his or her judge the same duty of confidentiality that the attorney owes his or her client.90 Two problems arise,

83 The Code of Judicial Conduct has been adopted by the Judicial Conferenco of the United States as the standard for all federal judges except Supreme Court Justices and by forty-three states as of January 1978. Thode, The Code of Judicial Conduct-The First Five Years in the Courts, 1977 UTAYI L. Rev. 395, 395.

84 The Code of Professional Responsibility has been adopted in all fifty states, usually with minor variations, as the standard of conduct for lawyers admitted to the bar. Armstrong, Codes of Professional Responsibility, in Professional RESPONSIBITY: A GUIDE FOR ATTORNEYS 1, 4 (1978).

85 A. Dileo \& A. Rubin, supta note 16, at 26.

86 ABA Code of Judrclar Conduct Canon 3B(2).

87 The survey revealed that some clerks specifically promise to conduct themselves in accordance with the Code of Judicial Conduct.

88 This is the rationale, for example, of the Code of Professional Responsibility. See text accompanying note 99 infra.

89 See, e.g., Aldisert, supra note 33, at 1256; Hamley, supra note 32, at 1241. Some survey respondents also characterized the clerk-judge relationship in this manner.

90 See ABA CoDe of Frofessional Responsmintry Disciplinary Rule 4-101. IThe Ethical Considerations and Disciplinary Rules of the Code of Professional Re- 
however, from a direct application of the attorney's duty to the law clerk. First, many clerks are not members of the bar during their clerkships and therefore would not be bound by the Code. Second, even for those clerks who are members of the bar, it is unclear whether the judge can be considered a "client" of the clerk, because the traditional clerk assigned to a particular judge is employed to assist that judge in performing a public function rather than to represent his or her personal interests.

The clerk's professional role seems more akin to that of the government lawyer ${ }^{01}$ than to that of an attorney representing a private client. Opinion 73-1 ${ }^{92}$ of the Federal Bar Association describes the difference between the private and the government attorney:

[The government] lawyer assumes a public trust ... [and] is responsible to the people in our democracy with its representative form of government. . . . In contrast, the private practitioner represents the client's personal or private interest. ... [W] do not suggest, however, that the public is the client as the client concept is usually understood. It is to say that the [government] lawyer's employment requires him to observe in the performance of his professional responsibility the public interest sought to be served by the governmental organization of which he is a part. ${ }^{93}$

Thus, although the public is not a client as that term is traditionally understood, the government attorney has a public responsibility. The client, "using the term in the sense of where lies [the government lawyer's] immediate professional obligation and responsibility," is identified as "the agency where he is employed, including those charged with its administration insofar as they are engaged in the conduct of the public business." 94 Furthermore,

sponsibility are hereinafter cited, respectively, as ABA Code of Professtonat Responsmintry EC and ABA Code of Professional Responsibmity DR.]

91 The federal government lawyer works for the military, the legislative branch, or an executive agency. Poirier, The Federal Government Lawyer and Professional Ethics, 60 A.B.A.J. 1541, 1541 (1974).

92 Fed. B. A. Comm. on Professional Etrics, Opinions, No. 73-1 (1973), reprinted in $32 \mathrm{FED}$. B.J. 71 (1973) [hereinafter cited as Opinions 73-1].

The difficulty identifying the client of the federal government lawyer was one of the considerations that prompted the Federal Bar Association to adopt, in November 1973, the Federal Ethical Considerations to supplement the ABA Code of Professional Responsibility. Poirier, supra note 91, at 1541 .

93 Opinion 73-1, supra note 92 , at 72 .

94 Id. 
"[t] he relationship is a confidential one, an attribute of the lawyer's profession which accompanies him in his government service. This confidential relationship is usually essential to the decision-making process ...." gs

If applied to the law clerk, this notion of responsibility would require the clerk to serve the "public interest" by assisting the judge in carrying out the court's judicial functions rather than the judge's personal or private interest. The client, in the sense of the clerk's "immediate professional responsibility," would be the court and those in charge of its administration-presumably including the judges-"insofar as they are engaged in the conduct of the public business." The relationship as so defined would be a "confidential one." Thus limited, the duty imposed by the Code of Professional Responsibility provides that "a lawyer shall not knowingly . . . [r]eveal a confidence or secret of his client." ${ }^{86}$ This obligation "continues after the termination of his employment," 97 and extends to refusing employment that "might require such disclosure." 88

A professional responsibility basis for a law clerk's confidentiality duty would provide a clearer and more uniform specification of the conduct expected of clerks both during and after their clerkships. Some survey respondents, for example, reported that breaches of confidentiality by clerks often were inadvertent or resulted from lack of awareness. These breaches and anonymous ones such as those involved in The Brethren might be avoided if there were a clearer sense that appropriate professional conduct bars such disclosures. Professional disciplinary sanctions such as denial of admission to the bar, disbarment, suspension, or reprimand could be employed in egregious cases, but the primary benefit of a professional conduct rule for law clerks would be prophylactic. As one commentator has observed:

95 Id. 72-73. Cf. ABA Comm. on Evaluation of Professtonal Standards, Model Rules of Professional Conduct Rule 1.12 (Woxking Draft, February 6, 1981) [hereinafter cited as Moder Rules of Professional Conduct]. Currently in the drafting and revision stage, these proposed rules treat lawyers employed by a governmental agency as representing the organization rather than management or other employees of the agency. The commentary to the rules notes that "[w]hen the client is a governmental organization, a different balance may be appropriate between maintaining confidentiality and assuring that the wrongful official act is prevented or rectified, for public business is involved." Id. Comment.

96 ABA Code of Professional Responsmitrty DR 4-101(B)(1). Cf. Moded. Rules of Professtonal Conduct Rule 1.6, supta note 95 (eliminates the confidences and secrets definitions and includes all "information gained in or relating to representation of the client.").

97 ABA Code of Professtonal Responsibitity EC 4-6.

98 Id. EC 4-5. 
While disciplinary bodies can deal with flagrant violators of the Code of Professional Responsibility, the ultimate enforcer of proper professional conduct is the conscience of the bar and the ethical standards of its individual members. Adherence to the overall spirit of the Code is ensured by the desire of lawyers to gain and maintain the respect of their fellow lawyers . . . .99

\section{Fiduciary or Contractual Duty}

As an employee, a law clerk may have a common law "fiduciary obligation to protect confidential information obtained during the course of his employment." 100 This duty not to use or disclose confidential information for personal gain would continue after termination of employment. ${ }^{101}$ A clerk also may be subject to a contractual duty to preserve confidentiality if he or she is required to sign a written agreement or to take an oath that includes such a promise. Nine percent of the survey respondents reported using such an oath or agreement, although the promises required vary in specificity and duration of the obligation. ${ }^{102}$ Sixty-three percent of the respondents mentioned fiduciary duty as a basis of

99 Armstrong, supra note 84 , at 18.

100 Snepp v. United States, 444 U.S. 507, 515 n.11 (I980) (per curiam) (dictum). See also Restatement (SECOND) OF AgenCy $\$ 395$ \& 396(b) (1958).

101 Restatement (Second) of Agency \$396(b) (1958).

102 Judges were requested to provide a copy of any instructions regarding confidentiality given to their clerks: A typical nonspecific instruction states: "All your working relations and information acquired in the course of service are highly confidential in character and must be treated and guarded by you on this footing." A more specific confidentiality duty is established by the following instructions, although the reference to "employees" leaves open the question of duration:

Employees shall not reveal to any person not a Court officer or employee:

(A) The Court's deliberations, discussion or other work product concerning decisions,

(B) The identity of a Judge assigned primary responsibility for a pending decision,

(C) the author of an opinion signed only by the Court, or

(D) Any other information or document which by the Court's local rules is confidential.

An oath that is specific about the continuing nature of the confidentiality duty provides:

I will maintain undivided loyalty to this Court and the judges thereof and, both during and after my term of service, I will keep their trust and preserve inviolate the confidences which they repose in me. I will not divulge any conversations or information regarding the business of the Court, or memoranda, or other writings, or disclose unannounced decisions of the Court, or keep any documents or other papers without the permission of this Court. 
the clerk's confidentiality duty; approximately twenty-two percent also indicated a contractual basis.

The duty of a former employee having access to confidential information normally involves commercial or technical trade secrets. $^{103}$ In Snepp $v$. United States, ${ }^{104}$ however, the doctrine was applied to a former Central Intelligence Agency (CIA) employee, Frank Snepp, who had access to sensitive classified information and published a book in violation of a secrecy agreement with the CIA. The agreement forbade the disclosure of "any classified information" " and required CIA approval prior to the publication of " any information or material relating to the Agency, its activities or intelligence activities generally, either during or after" " employment. ${ }^{105}$ Despite this agreement, Snepp published a book without prior clearance. The United States did not contend that the book contained any classified information; ${ }^{106}$ nevertheless, the Supreme Court upheld the district court's finding that Snepp had breached his contractual and fiduciary obligations. ${ }^{107}$ The lower court's imposition of a constructive trust on the book's profits in favor of the CIA thus was approved as a proper remedy. ${ }^{108}$ The Court relied on the "extremely high degree of trust" involved in the employment and the language of the agreement that explicitly recognized this trust. ${ }^{109}$ Moreover, the Court stated that the "nature of Snepp's duties and his conceded access to confidential sources and materials could establish a trust relationship" even in the absence of a written agreement. ${ }^{110}$

103 Ricketson, Confidential Information-A New Proprietary Interest? Part I, 11 MeLbourne U. L. Rev. 223 (1977).

104444 U.S. 507 (1980) (per curiam).

$1051 d .508$ (quoting the agreement).

108 Id. 511.

107 Id. 516. Snepp's violation of his trust did not depend on whether the book contained classified information. His failure to submit the book for review, in light of the secrecy agreement and the trust reposed in him as an intelligence employee, was sufficient to find a violation. The Court found that publication of unreviewed unclassified material might harm Snepp's employer by exposing classified information or confidential sources or by affecting some foreign governments' willingness to cooperate with the CIA. Id. 511-13. (1958).

108 Id. 515-16. See generally RESTATEMENT (SECOND) of AGENCX \$396(c)

109444 U.S. at 510.

210 Id. 511 n.6 (dictum). The majority believed the constructive trust doctrine covered more than disclosures of classified information. Id. 515 n.11. Snepp's defense of prior restraint of his first amendment rights was summarily rejected in a footnote-the Court stated that the secrecy agreement was an "entirely appropriate' exercise of the CIA Director's statutory mandate to 'protec[t] 
To the extent that the position of the law clerk is viewed as one of great trust, a useful analogy to Snepp can be drawn. A written agreement would result in a clear contractual duty to preserve confidentiality. Even absent a signed agreement, however, the confidential nature of the clerkship ${ }^{111}$ seems sufficient to invoke the common law fiduciary obligation of present and former clerks to preserve confidentiality, ${ }^{112}$ especially if specific oral or written instructions are given at the beginning of the clerkship. ${ }^{113}$

A cause of action based on a breach of the clerk's contractual or fiduciary obligations thus could be maintained against present or former law clerks disclosing confidential communications or documents. The potential remedies in such actions, however, make them unsatisfactory methods of protecting the confidentiality of the inner workings of the courts. Damages for breach of contract probably would be nominal because of the unquantifiable nature of the injury.114 An injunction against future breaches usually would come too late. Imposing a constructive trust would be useful only in situations where the clerk's unlawful disclosure was made for profit. None of these remedies would be applicable in a case where the identity of the one disclosing confidential information is unknown, as in The Brethren. ${ }^{115}$ The only likely salutary effect of requiring written or oral agreements, therefore, is a greater awareness of the solemnity and content of the confidentiality duty.

intelligence sources and methods from unauthorized disclosure." " Id. 509 n.3 (quoting the Court of Appeals and 50 U.S.C. $\$ 403$ (d)(3) (1976)).

111 See text following note 17 supra. Federal law clerks are classified as "confidential employees." ABA CoMm. ON Standards OF Judicial ADMmistration, Standards Relating to Court Organtzatton $\$ 1.42$ (b)(iii) (1974).

112 The United States Court of Appeals for the Fourth Circuit, upholding the validity of another CIA secrecy agreement, noted the needs of the various branches of government for secrecy and quoted with approval the statement that " "It]he courts, too, often insist on the confidentiality of deliberations .... in judicial chambers. The most confidential proceeding in all of government is probably the conference of the Justices of the Supreme Court." "United States v. Marchetti, 466 F.2d 1309, 1316 (4th Cir.), cert. denied, 409 U.S. 1063 (1972) (quoting Henkin, The Right to Know and the Duty to Withhold: The Case of the Pentagon Papers, 120 U. PA. L. REv. 271, 274 (1971)).

113 See note 102 supra for examples of law clerk instruction currently used by judges.

114 The Court in Snepp, for example, noted that the actual damages involved in Snepp's breach were unquantifiable and that nominal damages would be an ineffective deterrent. 444 U.S. at 514.

115 B. WOODWARD \& S. ARMSTRONG, supra note 1 , at 3.

Even when the identity of the individual breaching confidentiality is unknown, however, the injured party might have a cause of action in tort against the party who induced the breach of contract. See W. Paosser, HaNdBook of THE LAW OF TORTS $\$ 129$ (4th ed. 1971). 


\section{Duty Imposed By Court Rule}

Some jurisdictions have local court rules governing disclosures by court personnel, including law clerks. ${ }^{116}$ These rules are limited as a basis for the clerk's confidentiality duty, however, because they generally apply only to pending cases, and because the limitation to "court personnel" excludes former personnel. Given the brevity of most clerkships, these court rules may protect information concerning pending cases, but they are an insufficient basis for the totality of a clerk's confidentiality duty.

\section{Proposed Confidentiality Guidelines}

In light of the multifaceted nature of the law clerk's position, ${ }^{117}$ the arguments for and against preserving confidentiality, ${ }^{118}$ and the varying bases of the clerk's confidentiality duty, ${ }^{119}$ no simple rule of nondisclosure is likely to resolve the confidentiality issue. Instead, a set of guidelines is needed, varying in scope and required enforcement according to the type of information involved. This Comment proposes guidelines to govern law clerks' conduct when they are asked to disclose information concerning pending cases, ${ }^{120}$ past cases, ${ }^{121}$ general decisionmaking practices of the court, ${ }^{122}$ the philosophy or personal traits of judges, ${ }^{123}$ or suspected or known wrongdoing involving judges or other court personnel. ${ }^{124}$ These proposed guidelines specify the minimum content of the law clerk's confidentiality duty that should be included in a mandatory professional conduct rule, above-the-minimum content that should be part of an "aspirational" guideline, ${ }^{125}$ discretionary content that should vary with the instruction of the individual judge or court, and information that is not part of the duty.

116 See note 36 supra and note 152 infra.

117 See text accompanying notes 24-28 supra.

118 See text accompanying notes 39-66 supra.

119 See text accompanying notes 67-116 supra.

120 See text accompanying notes 137-49 infra.

121 See text accompanying notes 150-60 infra.

- 122 See text accompanying notes 161-70 infra.

123 See text accompanying notes 171-81 infra.

124 See text accompanying notes 182-92 infra.

125 An "aspirational" guideline would be similar to the ethical considerations in the Code of Professional Responsibility that "represent the objectives toward which every member of the profession should strive." ABA CODE OF Professionar. REsponsmintry, Preliminary Statement. The Model Rules of Professional Conduct do not separate rules from ethical considerations. Some rules, however, are "imperatives"; others "define areas in which the lawyer has professional discretion." Model Rules of Professional. Conduct, supra note 95, at 4. 
The minimum and "aspirational" content of the confidentiality duty should be incorporated in a code of professional conduct specifically applicable to current and former law clerks. The primary benefit of such a code would be prophylactic, but disciplinary sanctions also would be available for egregious breaches involving the minimum mandatory content. ${ }^{128}$ To promote uniformity, the American Bar Association should adopt the proposed guidelines and encourage their adoption by state and federal courts. ${ }^{127}$ Adding the law clerk guidelines to the ABA Code of Judicial Conduct, for example, would be an efficient method of enforcing the minimum mandatory content of the duty.

The brevity of many clerkships makes essential a procedure that will reach former as well as current clerks. Current clerks could be covered by existing judicial disciplinary machinery enforcing the Code of Judicial Conduct, ${ }^{128}$ court rules, ${ }^{129}$ and private sanctions by their employers. ${ }^{130}$ Former clerks could be covered by the existing lawyer disciplinary procedures enforcing the ABA Code of Professional Responsibility. ${ }^{131}$ Standards recently adopted by the American Bar Association for lawyer discipline make violation of the Code of Judicial Conduct a ground for discipline under the Code of Professional Responsibility. ${ }^{132}$ Former judges resuming their lawyer status may be disciplined under these standards even if their misconduct occurred while they were judges. ${ }^{133}$ Similarly, a former clerk's past or present violation of the Code of Judicial Conduct could be made a ground for lawyer discipline. The sanc-

126 See text following note 98 supra and text accompanying note 99 supra.

127 The ABA Code of Professional Responsibility and the ABA Code of Judicial Conduct were adopted first by the American Bar Association, then by most of the states. Armstrong, supra note 84, at 4; Thode, supra note 83, at 395 .

128 Each jurisdiction adopting the Code must establish its own disciplinary procedures and penalties. Thode, supra note 83 , at 396 . Sanctions for violating the Code have included private or public censure and removal from office. Id. 400-13. Cf. New York Times Co. v. United States, 403 U.S. 713, 752 n.3 (1971) (Burger, C.J., dissenting) (Court has "inherent power ... to protect the confidentiality of its internal operations by whatever judicial measures may be required").

129 See text accompanying note 116 supra.

130 See text accompanying note 114 supra.

131 Disciplinary procedures for lawyers vary widely among states. Armstrong, supra note 84, at 17 . Current procedures and enforcement have been subject to heavy criticism. See, e.g., ABA Spectad, Comm. on Evaldution of Disciplinary ENForcenenT (1970). The American Bar Association recently has adopted new standards for disciplinary proceedings, however, that may lead to improvement and

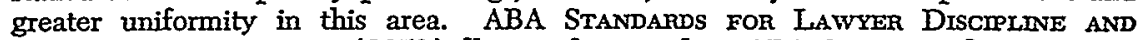
Disability Proceedings (1979) [hereinafter cited as ABA Standards].

132 ABA STANDARDS $\$ 5.1$ (d), supta note 131 .

$133 \mathrm{Id}$. \$ 4.5. 
tions ${ }^{134}$ imposed for a violation should be based upon the facts and circumstances of the case and the purpose of lawyer discipline ${ }^{135}-$ "to protect the public and the administration of justice from lawyers who have demonstrated by their conduct that they are unable or are likely to be unable to properly discharge their professional duties." 138

\section{A. Pending Cases}

Guideline: $A$ law clerk should never disclose [outside the court family] information concerning the assignment, scheduling, internal deliberations, or outcomes of pending cases that is not in the public record. ${ }^{137}$

Commentators ${ }^{138}$ and judges ${ }^{139}$ agree that information concerning pending cases should be within the scope of the law clerk's confidentiality duty. Survey respondents unanimously included such information in the clerk's duty. Moreover, thirty percent of the respondents indicated that current clerks have a higher duty of confidentiality than former clerks precisely because the potential harms of a breach are greater in a pending case. Even those judges who felt that the duty of current and former clerks is the same often commented that negative consequences are likely to be greater if information about a pending case is disclosed. The potential harms of such a breach include giving an unfair advantage to one of the litigants or the others affected by the decision, ${ }^{140}$ undermining public confidence in the judiciary by creating an appearance of partiality, ${ }^{141}$ and interfering with frank deliberations within the court. $^{142}$

134 Possible sanctions under the new ABA disciplinary standards include disbarment, suspension, probation, public reprimand, private admonition, restitution, and assessment of costs. Id. \$6. For clerks who are not licensed lawyers when a breach occurs, the breach could be considered when they apply for admission to the bar.

$135 \mathrm{Id}$. $\$ 7.1$.

136 Id. $\$ 1.1$.

137 This guideline is limited by the wrongdoing exception discussed in note 182 infra and text accompanying notes 182-92 infra.

138 See, e.g., Bender, supra note 6, at 721. But of. Miller \& Sastri, supra note 12 (argue that appellate court deliberations should be open to the public).

139 All survey respondents agreed that the confidentiality duty extends to information about pending cases; eighty percent felt this duty also extends to matters of public record.

140 For example, leaks by a Supreme Court clerk concerning a pending case were used to speculate on the stock market. P. Barnett, supra note 19 , at $I$.

141 See text following note 48 supra.

142 See notes $39-41$ supra \& accompanying text. 
Many courts or jurisdictions forbid discussion about pending cases by court rule ${ }^{143}$ or by adoption of the Code of Judicial Conduct. 144 Canon $3 \mathrm{~A}(6)$ of this Code provides: "A judge should abstain from public comment about a pending or impending proceeding in any court, and should require similar abstention on the part of court personnel subject to his direction and control." Presumably, clerks are made aware of this duty. Commonly used law clerk manuals also make this duty clear. ${ }^{145}$ Moreover, in view of the judiciary's strong feelings concerning the impropriety of disclosing information about pending cases, most judges probably give at least an oral instruction to their clerks regarding confidentiality.

The controversial issues concerning pending cases are whether a clerk should talk freely within the court family, and whether a clerk should discuss matters that are of public record. Because of the range of opinions expressed by judges with regard to the first issue, ${ }^{146}$ it seems preferable to leave instructions concerning discussion within the court to the individual judge or court rather than to articulate a general rule. For example, a sensitive political climate within an appellate court may mean that discussions between clerks about their judges would impair the decisionmaking process or undermine one judge in the view of others in the court family. In such situations, a judge may wish to limit the clerk's discussions with other clerks and judges.147 The personal relationship between judge and clerk also favors leaving this decision to the individual judge. Ideally, however, prohibition of intracourt discussion will be kept to a minimum in order to enhance the educational value of a clerkship. ${ }^{148}$

Pragmatic arguments favor prohibiting clerks from discussing matters of public record concerning pending cases; eighty percent of the survey respondents agreed with such a prohibition. The reason usually given was the inability of inexperienced clerks to distinguish adequately what is from what is not part of the public

143 See note 36 supra \& accompanying text.

144 See text accompanying notes $85-87$ supra for discussion of applicability of the Code of Judicial Conduct to law clerks.

145 For example, a handbook used by some federal judges provides that the "law clerk must resolutely refrain from making any statement, public or private regarding pending proceedings." A DILEO \& A. RUBIN, supra note 16, at 43 .

${ }^{146}$ See notes 31-34 supra \& accompanying text.

147 Cf. ABA Code of Professional Responsibility DR 4-101(A) (Attomeys have a duty to preserve their clients' secrets, including "information gained in the professional relationship that the client has requested be held inviolate."). Judges similarly may wish to keep some "secrets" from their colleagues.

148 See notes 18-19 supra \& accompanying text. 
record. A blanket prohibition thus would protect against mistakes in the highly sensitive area of pending litigation. This concern was articulated by one judge as follows:

It is impossible for a law clerk to separate what he or she knows from the public record from confidential information. Even if the clerk were to confine himself or herself to the public record it would be perceived to be something more. Finally, there is no need to inquire of the law clerk about what is in the public record. That [finding out public information] is not the purpose of the [one making the] inquiry. ${ }^{140}$

The very notion of confidentiality, however, embraces matters that are not generally known. Information of public record, therefore, should be excluded from the duty of confidentiality. Any public record prohibition should remain a prudential rule at the discretion of each judge or court, rather than a professional conduct rule with its attendant sanctions.

\section{B. Past Cases}

Guideline: A law clerk should never disclose information concerning the details of decided cases that is not in the public record [for $X$ years] without permission of the court. This duty continues after termination of employment. 150

After a case has been decided, there no longer exists the potential danger of unfairness to litigants that is present whenever confidential information about pending cases is disclosed. ${ }^{\mathbf{1 5 1}}$ Disclosing confidential information about a case after the decision may cause other harm, however, such as impairment of frank discussion, dam-

149 One judge who would not require a blanket prohibition nevertheless sounded a similar cautionary note:

With respect to the duty of confidentiality as to litigated matters, I see no ground for requiring a law clerk to refrain from reference to matters which clearly are of "public record"-e.g., the identity of counsel for plaintiff. But I think a law clerk must be very certain that a particular datum is, in fact, "of public record." Prudence dictates that any doubt ... be resolved in favor of preserving confidentiality.

All of the judges who reported experiencing a breach of confidentiality would prohibit references even to matters of public record. This response, encompassing one of the few areas in which a notable difference existed between those who had and those who had not reported a breach, probably is explained by the maxim "once burned, twice shy."

160 This guideline is limited by the wrongdoing exception discussed in text accompanying notes 182-92 infra.

181 See note 140 supra \& accompanying text. 
age to the judge-clerk relationship, possible compromise of the judiciary's independence, and threats to the opinion as the sole rationale of the case. Survey respondents, mentioning these concerns, unanimously extended the clerk's confidentiality duty to information about past cases, although only about one-half would prohibit discussion about matters of public record, and some expressed qualifications concerning the time limit.

The Code of Judicial Conduct and many local court rules refer specifically to pending cases; ${ }^{152}$ they provide little guidance concerning cases already decided. If a law clerk is defined as a confidential employee ${ }^{153}$ with a professional responsibility analogous to that of a government lawyer, ${ }^{154}$ however, the details of past cases not of public record can be included in a clerk's confidentiality duty. The government lawyer's immediate professional responsibility is to his or her agency and those charged with its administration insofar as they are engaged in public business. ${ }^{165}$ To this extent, the government lawyer's employment relationship is a confidential one, and his or her professional confidentiality duty continues after employment terminates. If this reasoning is applied to the clerk-judge relationship, then information concerning the internal deliberations of decided cases should be kept confidential by current and former clerks, unless it is already part of the public record.

The fiduciary basis of a law clerk's duty provides support for a similar conclusion. The clerk's confidentiality duty, based on his or her position as a trusted employee, ${ }^{150}$ would continue after employment terminates, at least if the duty has been made clear at the outset.

For these reasons, information concerning the details of decided cases that is not in the public record should be included in a mandatory professional conduct rule. On the other hand, arguments that the public needs to know about the decisionmaking

162 See note 36 supra and text accompanying notes 36 \& $143-44$ supra. Cf. D. MAss. R. 36, which arguably includes information about past cases in its prohibitions:

All courthouse personnel, including among others . . . law clerks, are prohibited from disclosing to any person, without authorization by the court, information relating to a criminal or civil case that is not of the public records of the court. The divulgence of information concerning arguments and hearings held in chambers or otherwise outside the presence of the public is also prohibited.

153 See notes 100 \& 111 supra \& accompanying text.

154 See notes 92-95 supra \& accompanying text.

165 See note 94 supra \& accompanying text.

156 See notes 108-12 supra \& accompanying text. 
process ${ }^{157}$ become more persuasive once cases are part of history. Moreover, judges themselves sometimes have revealed the internal deliberations or compromises involved in past cases, ${ }^{158}$ a fact weakening the argument in favor of keeping such information confidential. ${ }^{159}$ An appropriate compromise, therefore, would be to allow law clerks to disclose information about decided cases either with the judge's permission or after a number of years has passed. ${ }^{\mathbf{1 6 0}}$

\section{General Decisionmaking Practices}

Guideline: Information about general internal procedural matters is not part of a law clerk's confidentiality duty and may be disclosed unless the judge specifically prohibits disclosure.

Although eighty-three percent of the survey respondents included information about the general decisionmaking practices and procedures ${ }^{161}$ of the judge or court within the scope of a law clerk's confidentiality duty (twenty-eight percent limited the duty to matters not of public record), public need for such information strongly supports permitting disclosure by law clerks. ${ }^{162}$ An exception would be made if the judge or a court rule specifically forbade such disclosures. The public cannot use the judicial system effectively unless general procedural information is readily available. ${ }^{163}$ Such information also is needed if the courts are to be open to informed criticism. ${ }^{164}$ The dangers of leaking information about pending cases or chilling internal discussions are absent in this context; disclosure would open court procedures and practices to rational debate, possibly resulting in improved systems. Moreover, revelations about internal procedures by former clerks are not a new phenomenon-much of what is known about the role and

157 See notes 61-64 supra \& accompanying text.

158 See, e.g., W.O. Douglas, supra note 1.

159 It has been suggested, however, that release of documentation about past cases is probably the exclusive prerogative of judges. Bender, supra note 6, at 722 . Cf. note 57 \& accompanying text (a law clerk's perspective may be limited or distorted).

160 Cf. 44 U.S.C. $\$ \$ 2201-07$ (Supp. III 1979) (ownership and possession of Presidential records is reserved to the United States; the Archivist of the United States assumes responsibility for custody and access after a President's term of office. The President is permitted to limit access to certain types of information - for example, confidential communications with advisors or national security matters-for a maximum of twelve years).

101 See question 1 (d), Appendix infra.

162 See Morrison, Focusing on the Wrong Secrecy, 66 A.B.A.J. 563 (1980).

$163 \mathrm{C} f$. ABA Code of Judictal Conduct Canon 3A(6) (permits judges to explain court procedures).

164 See notes 59-64 supra \& accompanying text. 
duties of law clerks has been provided in various reminiscences by clerks. ${ }^{165}$ A substance-procedure distinction is, therefore, a valid and practical way of resolving the confidentiality issue in this area. ${ }^{168}$

There remains the question of an appropriate forum for law clerk comments. Ninety-five percent of the survey respondents rejected investigative journalism as an appropriate forum because of suspicions that journalists are interested only in sensationalism and "gossip or worse," and that journalists' reports are subjective, inaccurate, and distorted. ${ }^{167}$ Similar criticisms have been made by commentators reviewing The Brethren. ${ }^{168}$ In light of these criticisms, the legal and academic community may provide a more appropriate forum for informed debate about court practices and procedures. ${ }^{169}$ It is inappropriate, however, to prohibit resort to one forum rather than another because of the clerks' first amendment rights of freedom of expression. Rather, this aspect of a clerk's confidentiality duty should be left to the individual clerk's judgment. ${ }^{170}$

105 See, e.g., The Bright Young Men Behind the Bench, U. S. NEws \& WorLD REPORT, July 12, 1957, at 45 (discusses opinions of Supreme Court Justices, former Supreme Court clerks, and others about the influence of law clerks).

166 See also Baier, supra note 19, at 1143 n.82.

167 Typical comments include: "If The Brethren is the model of investigative reporting, it proves the undesirability of this practice. It was not to inform; it was to impugn without factual basis and denigrate an institution" and "so-called 'investigative journalists' are inherently unreliable, have no ethical standards and are interested only in scurrilous material, not the truth."

Justice Douglas commented:

[t]he American press ... is by and large a mimic, not an original research group. It prints handouts from government and from industry and expresses its opinion on those items. But the basic facts are seldom mined; the press does not have the initiative or the zeal to ferret out the original from the false or pretended.

W.O. Douglas, supra note 1, at 206-07.

168 See, e.g., Daniels, supra note 11 , at 733 (The Brethren was guided by an inappropriate muckraking model); Henry, supra note 9 , at 495 (the book "has no historical value or legal significance" and is poorly documented); Kurland, supra note 10, at 193 ("[n] lothing in The Brethren comes close to ... reasoned criticism of the Court's work"); Navasky, supra note 55, at 1033 (the book involves "distortion"). The muckraking and ethical shortcomings of the media also have been noted by a journalist. See Broder, The Media-Monitors of Virtue?, 55 CHn. B. REc. 19 (1974) (special centennial issue).

169 For example, a recent study of the California courts' practices concerning the use of law clerks was conducted by interviewing judges and clerks; the results were presented in the form of composite typical judges, thereby insuring the anonymity of individual judges. See Oakley \& Thompson, supra note 18.

170 In order to avoid jeopardizing pending litigation, judges may wish to instruct clerks not to speak with the media during their tenure about court-related matters. See text following note 148 supra. 


\section{Philosophies and Traits of Judges}

Aspirational Guideline: A law clerk should never disclose information concerning a judge's philosophy and personality that is not in the public record if the judge expressly requests that such information remain confidential or if disclosure would be embarrassing to the judge or to the court.171

The philosophy and personality traits of judges should not be included in the minimum mandatory content of a clerk's professional duty, with its attendant sanctions, because of the predominantly personal nature of the information. An aspirational rule, on the other hand, proscribing disclosure of information expressly requested to be kept confidential or that clearly would embarrass the judge or court, is appropriate. ${ }^{172}$ Such a guideline has the benefits of clarifying what ideally is expected of law clerks and of covering those clerks for whom the loyalty basis for the confidentiality duty might be inadequate-for example, central staif clerks or clerks having irreconcilable personal or philosophical differences with their judges. ${ }^{173}$

Eighty-two percent of the survey respondents felt that the law clerk's confidentiality duty extends to information about personality traits and social and political philosophies of judges. A law clerk handbook used by some federal judges takes a similar view concerning philosophies.174 Judges expressed concern that discussion would be limited if such disclosures were feared, thereby impairing the decisionmaking process and the judge-clerk relationship, ${ }^{175}$ and jeopardizing the independent reasoning of the judiciary. 176 On the other hand, to the extent that a judge's personality and philosophy enters the decisionmaking process, particularly in states with elected judges, the public may be deprived of relevant information by an internal wall of secrecy..$^{177}$

171 This guideline is limited by the wrongdoing exception discussed in text accompanying notes $182-92$ infra.

172 Such a rule thus would make ideal for the law clerk what is mandatory for the private attorney. See note 179 infra.

173 See text accompanying notes 79-82 supra.

174 The handbook provides: "The clerk must absolutely forswear all informal discussions of . . the judge's views on any particular legal or social issues. If judges wish to publish their jurisprudential, economic or social views, they know how to do so." A. DiLeo \& A. RuBin, supra note 16, at 43.

175 See notes 40-44 supra \& accompanying text.

178 See text following note 45 supra. Judges also expressed concern about "bringing the personality of the judge into an objective decision," fearing that litigants may be apprehensive about the fairness of trials if the judge's philosophy is publicized.

177 See notes 61-62 supra \& accompanying text. But see note 63 supro (questioning whether personal factors that enter a decision are ascertainable in many cases). 
If a law clerk's position is analogous to that of the government lawyer, ${ }^{178}$ the judge is not the clerk's client in the traditional sense. ${ }^{179}$ Rather, the relationship is confidential only insofar as judges are engaged in "public business." Judges may be accomplishing their public functions when they discuss personal opinions and philosophies with clerks, but such discussions more often reflect the personal relationship between judge and clerk. ${ }^{180}$ The loyalty basis for the confidentiality duty, ${ }^{181}$ and the consequent reliance on the clerk's judgment, are thus appropriate enforcement mechanisms in this area.

\section{E. Wrongdoing Exception}

Guideline: A law clerk having knowledge of specific wrongdoing involving the court may disclose information that otherwise would be confidential. Such disclosure ordinarily should be made to the authorities charged with responsibility for disciplinary action against judges or other court personnel. 182

Aspirational Guideline: Suspicion of wrongdoing involving the court ordinarily is insufficient to justify disclosure of information within the mandatory scope of the confidentiality duty.

Judges are not "clients" of their clerks; ${ }^{183}$ the ethical considerations that normally give rise to the lawyer's confidentiality

178 See note 92 supra and text accompanying notes 92-95 supra.

179 The traditional attorney-client relationship requires that the attorney keep the client's "confidences" (defined as matters within the attorney-client evidentiary privilege) and "secrets" (defined to include matters that might be embarrassing or are designated as secret by the client). ABA Code of Professional ResponSIBIIITY DR 4-101. Under this model, any information that the judge specifies should not be revealed or any matters that would be "embarrassing" to the judge would be included in the clerk's confidentiality duty. Cf. MODEL RuLes of ProFEsstonal Conduct Rule 1.6, supra note 95 (eliminates the "confidences" and "secrets" notions of an attorney's duty and adopts a coverage of all "information gained in or relating to representation of the client").

$180 \mathrm{Cf}$. Opinion 73-1, supra note 92 , at 72 (the government attorney's professional responsibility is unlike the private attorney's representation of his or her client's private interest).

181 See text accompanying notes 74-82 supra.

182 Wrongdoing should include, for example, criminal activity, corruption, and violations of the $A B A$ Code of Judicial Conduct.

Compare the attorney's professional responsibility to breach the confidential relationship with his or her client if necessary to reveal the "intention of his client to commit a crime and the information necessary to prevent the crime." ABA Code of Professional Responsubirty DR 4-101(C)(3). Some misprision statutes also override the attorney-client privilege. See Shipman, Professional Responsibilities of the Corporations Lawyer, in Professronar ResponsIBIrTr: A GUIDE FOR ATTORNEYS 271, 228 (1978); 18 U.S.C. $\$ 4$ (1976) (one who conceals commission of a felony may be fined or imprisoned or both).

183 See text accompanying notes 89-95 supra. 
duty, ${ }^{184}$ therefore, are not present in the clerk-judge relationship. ${ }^{185}$ A subpoena to testify, such as the one involved in the Califormia investigation, ${ }^{186}$ thus would justify disclosure of otherwise confidential matters. ${ }^{187}$ Specific knowledge of wrongdoing also would justify disclosure, but the first resort should be to the proper authority rather than to the media. ${ }^{188}$

Many commentators who were critical of law clerk disclosures to the authors of The Brethren or of clerks testifying publicly in the California judicial commission investigation indicated they might feel differently if evidence of specific wrongdoing had been uncovered. ${ }^{189}$ The vast majority of survey respondents also felt that knowledge of specific wrongdoing involving the court or a subpoena to testify before a judicial commission would justify a breach of confidentiality by a current or former law clerk. ${ }^{190}$

184 See ABA Code of Professional Responsmintry EC 4-1. ("Both the fiduciary relationship existing between lawyer and client and the proper functioning of the legal system require the preservation by the lawyer of confidences and secrets of one who has employed or sought to employ him.") (footnote omitted).

185 Concealment of a judge's wrongdoing should not be necessary to maintaining the judge-clerk relationship. Moreover, because the clerk is not personally representing the private interests of the judge, the possible injury to the relationship cannot outweigh the benefits gained by disclosure of wrongdoing involving judges or other court personnel. See note 184 supra.

186 See notes 5 \& 7 supra \& accompanying text.

187 Cf. United States v. Nixon, 418 U.S. 683, 708-09 (1974) ("The expectation of a President to the confidentiality of his conversations and correspondence, like the claim of confidentiality of judicial deliberations, for example, has all the values to which we accord deference for the privacy of all citizens. . . " But, interest in criminal justice and the "integrity of the judicial system and public confidence in the system depend on full disclosure of all the facts. . . .").

Whether a judicial investigation is held in public or in private is outside the clerk's control and should not affect the clerk's duty to testify.

188 Cf. Opinion 73-1, supra note 92 , at 73 (government lawyers may disclose corrupt or illegal conduct to the "Thead of the department or agency" . . . who shall report it to the Attorney General"). The opinion notes that:

disclosure beyond the confines of the agency or other law enforcing or disciplinary authorities . . . is warranted only in the case when the lawyer, as a reasonable and prudent man ... concludes that these authorities have without good cause failed in the performance of their own obligation to take remedial measures required in the public interest.

Id. 74-75.

Cf. Model Rules of Professtonal Conduct Rule 1.12, supra note 95 (lawyer representing an organization and knowing of illegal conduct "likely to result in significant injury to the organization" shall seek to prevent the injury by "referring the matter to higher authority in the organization, including ... referral to the highest authority" before disclosing "information gained in or relating to the representation of the organization").

189 See, e.g., Kurland, supra note 10, at 190; Lewis, supra note 11, at 212; Tribe, supra note 10, at 1178 (the strong presumption of the confidentiality of a court's internal deliberations is not absolute).

100 See question 2 of Appendix infra, for wording of the question. Eightyfour percent of the survey respondents indicated that a subpoena would justify a breach, although twenty-five percent would limit the exception to private investigations. Eighty percent believed that knowledge of specific wrongdoing would 
A closer question is whether confidential information should be disclosed merely on the basis of suspicion of wrongdoing. Only about one-third of the survey respondents felt suspicion of wrongdoing would justify disclosure of confidential information. They emphasized that clerks ordinarily are not sufficiently informed or experienced to make competent judgments and that ill-founded suspicion could lead to baseless rumors or damaged reputations. ${ }^{191}$ In light of these dangers, drawing the line for disclosure at knowledge, rather than at suspicion, is preferable, although suspicion of wrongdoing should be included in an aspirational guideline. ${ }^{192}$

\section{Conclusion}

The law clerk's duty to preserve confidentiality has not been well-defined because of the multifaceted nature of the judge-clerk relationship, the many arguments for and against preserving confidentiality, and the varying bases for the clerk's duty. Neither the loyalty of clerks nor the remedies usually provided under contractual or fiduciary theories furnish sufficient assurance that confidential information will be protected.

This Comment has proposed that a set of guidelines be adopted to govern the law clerk's confidentiality duty, with enforcement varying according to the type of information involved. Under these guidelines, the clerk's duty to preserve confidentiality would extend to information not of public record about pending or past cases. Clerks would be permitted to discuss general procedural information; information about judges' philosophies and personalities not of public record would be left to the personal loyalty of the clerk and an "aspirational" rule. Knowledge of specific wrongdoing would be sufficient to justify disclosure of confidential information, although mere suspicion of wrongdoing would not be sufficient. The guidelines would be .enforced by disciplinary action similar to that currently used to enforce the ABA Code of Professional Responsibility. The proposed guidelines, if adopted, thus would provide law clerks with a clear, uniform idea of the scope of their confidentiality duty.

justify a breach, although one-third of these respondents would limit the exception to private investigations.

101 For discussion about judges' privacy and reputation interests and the distortions of a law clerk's perspective, see notes 54-57 supra \& accompanying text. 192 Cf. Opinion 73-1, supra note 92 , at 74 ("With respect to . . . conduct about which there may be reasonable differences of opinion as to its legality, and grossly negligent conduct ... [o]rdinarily there is no need of disclosure of such conduct beyond the personnel of the agency where it arises."). 


\section{APPENDIX}

In November 1980, the survey questionnaire was mailed to 375 state and federal judges, 111 of whom replied, constituting a response rate of approximately thirty percent. The sample population was defined as judges who use law clerks. In order to obtain as broad a cross-section of opinion and practice as possible, both federal and state judges at all three levels of courts were included in the sample. All United States Supreme Court Justices and courts of appeals judges were included, and a one-in-five sample of district court judges was taken. Five appellate judges from each of twenty-five states ${ }^{1}$ were included. Because of the difficulty ascertaining whether particular state trial court judges employed law clerks, only a small sample of these judges was taken.

Although a thirty percent response rate compares favorably with the response rate of many postal questionnaire surveys, ${ }^{2}$ the response rate was not high enough to warrant statistical statements, ${ }^{3}$ and the percentage results presented in the Comment should not be so read. Nevertheless, a number of factors extrinsic to the response rate suggest at least some validity to the results. The threat of bias in the results stems largely from the possibility that respondents and nonrespondents form different populations that vary significantly on the questions asked. ${ }^{4}$ Although judges with stronger opinions on the issue of law clerk confidentiality probably were more likely to respond, ${ }^{5}$ responses were received from all levels of the state and federal court systems, and a wide range of opinions and practices was reported. Moreover, the unanimity or near unanimity of the responses to some questions suggests at least a sizeable group consensus on certain issues. ${ }^{\theta}$ More caution should be exercised in interpreting the lower percentage results; nevertheless, even these findings suggest a split of opinion within the judiciary.

1 States were selected alphabetically, every other one.

2 See M. Parten, Surveys, Polls, and Samples: Practicat Procedures 391-96 (1966).

3 See C. Moser \& G. Katton, Survey Methods in Soctal Investigation 166-67 \& 268 (2d ed. 1972).

4 See id. 167-69.

- See id. 268; M. Parten, supta note 2, at 391-92.

- See questions $1(\mathrm{a})-(\mathrm{b}) \& 2(\mathrm{c})$ of the questionnaire, infra. 


\section{QUESTIONNAIRE}

1. In Your View, Does a Law Clerk's Duty to Maintain ConFIDENTIALITY EXTEND TO INFORMATION ABOUT:

(a) pending or impending cases? (please tick as appropriate)

(b) past cases?

(c) any conversation with a judge regardless of topic?

(d) general decisionmaking practices of court or judge?

(e) personality traits and social/ political philosophies of a judge?

(f) other areas? (please specify)
$80 \%$ Yes

$20 \%$ Only to matters not of public record

$0 \%$ No

$51 \%$ Yes

$49 \%$ Only to matters not of public record

$0 \%$ No

$49 \%$ Yes

$51 \%$ No

$55 \%$ Yes

$28 \%$ Only to matters not of $18 \%$ No public record

$64 \%$ Yes

$17 \%$ Only to matters not of public record

$19 \%$ No

.... Yes

.... No

Please describe your reasons for each of the above answers.

2. Would Any of the Following Circumstances Justify a Current or Former Law Glerk's Revealing Confidential Material?

(a) knowledge of specific wrong$80 \%$ Yes doing involving the court? $20 \%$ No suspicion of wrongdoing $34 \%$ Yes involving the court? $66 \%$ No

Why or why not?

(b) a subpoena to testify before a $59 \%$ Yes judicial commission investigation? $25 \%$ Only if held in private $16 \%$ No

Why or why not? 
(c) investigative journalism?

$5 \%$ Yes $\quad 95 \%$ No

Why or why not?

(d) historical or other scholarly research?

Why or why not?

3. Does a Current law Clerk Have a Greater Duty of ConFIDENTIALITY Than a Former Clerk?

Why or why not?

$30 \%$ Yes $70 \%$ No

4. From What Basis Does the Duty of Confidentiality Derrve IN YouR VIEW?
(a) $51 \%$ code of professional responsibility
(b) $20 \%$ court rules
(c) $3 \%$ statute
(d) $22 \%$ contract
(e) $63 \%$ fiduciary duty
(f) $31 \%$ other (please specify).

5. Do You (or Does Your Court) Use ANy of the Following Procedures/Practices Concerning the Confidentiality of Your LAW CLERKS:
(a) oral instructions
$94 \%$ Yes $\quad \ldots$ No
(b) guidelines in manual for law clerks
$50 \%$ Yes $\quad \ldots$ No
(c) oath promising confidentiality
$6 \%$ Yes $\quad \ldots$... No
(d) written agreement promising confidentiality
$6 \%$ Yes $\ldots$ No
(e) local court rules
$15 \%$ Yes $\quad \ldots$ No
(f) other (please specify).
$6 \%$ Yes $\quad \ldots$ No

If "Yes" to any of the above, please describe content and (where relevant) enclose a copy with your reply.

6. Have You or Other Members of Your Court Experienced Any Incidents You Consider to Be Breaghes of ConfidentiALITY BY LAW CLERKS?

$$
18 \% \text { Yes } \quad \ldots \text { No }
$$

If "Yes," please describe the nature of the incident(s) and consequences (e.g. greater security measures, sanctions imposed, etc.). 
7. How Might (OR Did) A Breach of Confidentiality by a Law Gleris Affect Your Relationship With Other Glerks, E.G., Would (OR DID) It Affect the Range/Type of Discussion or Your Preference for Hiring OnLy Permanent Crerks?

8. Please Describe Any Recommendations You May Have for a Systematic Policy and/or Enforcement Mechanism Concerning Law Clerk Confidentiality. 